https:// doi.org/10.18485/iipe_cpti.2020.ch7

\title{
NAPREDNE TEHNOLOGIJE PROTIV GLOBALNE PERIFERIJE: NESMRTONOSNO ORUŽJE U BUDUĆIM DISCIPLINSKIM RATOVIMA
}

\begin{abstract}
Srđan T. KORAĆ
Apstrakt: Rad analizira kako praktično-politička upotreba naučnih i tehnoloških dostignuća Četvrte industrijske revolucije ugrađenih u nesmrtonosno oružje, kao novo sredstvo američke politike intervencionizma, može da osnaži delotvornost kontrole globalne periferije radi disciplinovanja "odmetnutih" entiteta, a u kontekstu očuvanja postojećih mehanizama distribucije moći i materijalnih resursa. Autor smešta polaznu pretpostavku u okvir kritičkih teorija međunarodne bezbednosti i međunarodnih odnosa, i njena provera treba da otkrije da li strukturne odlike nesmrtonosnog oružja mogu da oblikuju nove načine optimalnog ostvarenja spoljnopolitičkih interesa, uzeto na primeru SAD, tačnije načine na koje supersila može da tehnološke potencijale tog oružja preinači u potencijal za očuvanjem osporene globalne dominacije. Istraživanjem je obuhvaćeno proizvedeno, prototipno i nesmrtonosno oružje u razvoju, zasnovano na naprednim tehnologijama zvuka, usmerene energije, sintetičke proizvodnje biohemijskih i hemijskih agenasa; u obzir su uzete i operativno relevantne strukturne odlike tog oružja, poput preciznosti, radijusa, ponovljivosti učinka, selektivnosti i sposobnosti pariranja konvencionalnom oružju. Autor zaključuje da bi društveno konstituisanje nesmrtonosnog oružja moglo u nastavku XXI veka da se odigra unutar logike disciplinskih ratova, te da ojača njenu demokratsku legitimizaciju tretiranjem pobunjenika sa globalne periferije kao "odmetnika” - "devijacije” spram neupitne univerzalističke civilizacijske misije (neo)liberalnog poretka.

Ključne reči: nesmrtonosno oružje, revolucija vojnih poslova, disciplinski rat, protivpobunjeničke operacije, globalna periferija, liberalni mir, SAD.
\end{abstract}

${ }^{1}$ Autor je viši naučni saradnik u Institutu za međunarodnu politiku i privredu, Beograd.

E-pošta: srdjan@diplomacy.bg.ac.rs.

Rad je nastao u okviru naučnoistraživačkog projekta „Srbija i izazovi u međunarodnim odnosima 2020. godine”, koji finansira Ministarstvo prosvete, nauke i tehnološkog razvoja Republike Srbije, a realizuje Institut za međunarodnu politiku i privredu tokom 2020. godine. 


\section{Društveno konstituisanje novog oružja i izmenjena ontologija nasilja}

Proizvodnja naučnog i tehnološkog znanja radi što efikasnijeg upravljanja složenim društvima jedan je od lajtmotiva pozitivističke paradgime. Na toj paradigmi je sazdan čitav misaoni okvir moderne i prateći model društvene organizacije nacionalnih država u okolnostima više talasa industrijskih revolucija. Reč je o uverenju da objektivni naučni rezultati omogućavaju da se predvidi smer ljudskog delanja, te da je na osnovu tih predviđanja moguća i primena birokratskih i disciplinskih procedura kako bi se kontrolisale njegove nepredviđene, a time nepoželjne posledice. ${ }^{2}$ Horkhajmer i Adorno (Max Horkheimer, Theodor Adorno) su ovu praksu nazvali pobedom instrumentalne racionalnosti, kritikujući uzdizanje korisnosti na nivo osnovnog merila rasuđivanja, orijentisanog isključivo na samoodržanje pojedinaca, a ne na traganje za istinom i krajnjom svrhom. ${ }^{3}$ Na tragu čuvene Koksove (Robert Cox) izreke da su teorije ",uvek za nekoga i u neku svrhu", krenućemo od pretpostavke da naučno i tehnološko znanje nikada ne ostaju van sfere političkog odlučivanja. Naprotiv, njihova praktično-politička upotreba ima suštinske posledice na distribuciju moći, materijalnih resursa i stvaranje prilika za ostvarivanje usvojenih političkih i ekonomskih interesa - bilo u okvirima jednog društva, bilo $u$ međunarodnim odnosima. ${ }^{4}$

Dostignuća Četvrte industrijske revolucije proširuju obzor delovanja $u$ međunarodnoj areni i iznova skreću pažnju na isprepletanost znanja/ tehnologije i moći u kontekstu održanja i uvećanja postojeće dominacije i hijerarhije u sistemu suverenih država i globalizovane ekonomije. Iz tog razloga, u ovom radu nastojaćemo da otkrijemo načine na koje napredna naučna znanja i tehnologije ugrađene $u$ nesmrtonosno oružje, mogu biti korišćeni zarad delotvornijeg sprovođenja vojnih intervencija velikih sila protiv nekooperativnih političkih entiteta globalne periferije. Pre nego

\footnotetext{
${ }^{2}$ Pitanje sposobnosti nauke da predviđa povezano je sa pitanjem instrumentalnog uspeha nauke. O tome više u: Alex Rosenberg, The philosophy of science: A contemporary introduction, Routledge, New York \& Oxon, 2005, pp. 95-97.

${ }^{3}$ Više pogledati u: Max Horkheimer i Theodor Adorno, Dijalektika prosvetiteljstva, "Veselin Masleša”, Sarajevo, 1974.

${ }^{4}$ Robert Cox, "Social Forces, States and World Orders: Beyond International Relations Theory", Millennium, Vol. 10, No. 2, June 1981, p. 128.
} 
pristupimo analizi središnjeg problema, sagledajmo ukratko kako se u ranom XXI veku oblikuje izuzetno čvrst i višeslojan odnos između čoveka i oružja kao tehničkog izuma i materijalnog predmeta, te koje nove kvalitete taj odnos donosi u kontekstu ratovanja kao društvene prakse.

Samoočevidno prihvatanje oružja kao sredstva rata često uklanja iz naučne debate pitanje striktne konceptualizacije šta je oružje, odnosno kako neki predmet postaje oružje. U kritičkim studijama ontologije nasilja ovo nije marginalan naučni problem, zato što nijedan proizvod ljudskog uma i ruku nije sam po sebi oružje. Neki predmet se preobražava u oružje spajanjem njegovih fizičkih svojstava sa društvenim kontekstom, te jedino skupa tvore potencijal za dominaciju posredstvom pretnje, i/ili proizvodnjom smrti i telesne destrukcije projektovanih na druge ljude. ${ }^{5}$ Utoliko Horkhajmerovo i Adornovo upozorenje o pogubnoj prevlasti instrumentalne racionalnosti jasno obuhvata i procenu korisnosti nekog predmeta, zasnovanu na svrsishodnoj materijalizaciji ljudske volje u vidu procesa racionalnog odlučivanja, usmerenog na mogućnosti upotrebe njegovog dizajna u nasilnim akcijama kako bi se očuvale osnovne vrednosti i interesi jedne države (ili grupe država). Budući da su gajeni pod okriljem realističkog pogleda na svet međunarodnih odnosa, vojni tehno-fetišizam i komercijalna utilitarnost vojne industrije postindustrijskih demokratija oduvek su u obrazlaganju spoljnopolitičkih odluka lako odnosili prevagu nad etički utemeljenim normativnim zahtevima za odbacivanjem upotrebe oružane sile kao načina rešavanja međunarodnih sporova. Utilitarno razmišljanje o tome da li i na koji način neki predmet pristankom naše slobodne volje postaje oružje u našim rukama, čini se da zatire upitanost da li su uopšte ispravni moralni razlozi njegove upotrebe na štetu drugih ljudi kao jednako vrednih bića.

Način na koji oružje ubija takođe je od suštinske važnosti, jer se on vremenom - kroz praksu -pretače u logiku ubijanja otelotvorenu u načelima normativnog poretka u čijim granicama se odvija vođenje ratnih operacija. Zbog toga je Niša Ša (Nisha Shah) proučavala kako smrtonosnost postaje

\footnotetext{
${ }^{5}$ Više o ovome videti u: Antoine Bousquet, Jairus Grove \& Nisha Shah, "Becoming weapon: An opening call to arms", Critical Studies on Security, Vol. 5, Issue 1, 2017, pp. $1-8$.

${ }^{6}$ Nisha Shah, "Death in the details: Finding dead bodies at the Canadian War Museum", Organization, Vol. 24, No. 4, 2017, pp. 549-569.
} 
legitimna kroz razvoj i unapređenje tehnološkog dizajna u pravcu uvećanja sposobnosti činjenja štete, $u$ spoju sa načinom ubijanja kao veštinom tesno povezanom sa dizajnom oružja, posebno onim njegovim karakteristikama koje omogućavaju da se podrže moralne norme vođenja rata. ${ }^{6}$ Šaova naglašava da načini na koje se tehničke karakteristike oružja standardizuju nisu samo povezane sa pitanjem povećanja efikasnosti; oni su i stvar legitimnosti ratovanja kao društvene prakse i to zato što oružje prouzrokuje povrede i smrt, i ujedno rađa prihvatljive načine na koje se smrt odigrava. ${ }^{7}$ Šaova obrazlaže da prihvatljivost neke vrste oružja kao "agenta destrukcije" počiva na načinima na koje je konstituišu tehničke karakteristike, uputstva za upotrebu, vojna strategija, ljudska ingenioznost i sklonost ka ratovanju, ali je i uslovljena moralnim svetonazorima i društvenim konvencijama o prikladnosti i neprikladnosti ciljeva i sredstava nasilja. ${ }^{8}$ Drugim rečima, pojedine vrste leševa i ranjenih tela su prihvatljive kao „uračunati troškovi”, odnosno oni se materijalizuju u ontologiji nasilja koja pojedine vrste oružja čini prihvatljivim za rat.

Odnos čoveka (vojnika/borca) prema oružju kao sredstvu nasilnih praksi pojavljuje se kao jednako važan činilac u društvenom konstituisanju pojedinih vrsta oružja. Za Bendžamina Meikisa (Benjamin Meiches) materijalna dimenzija oružja, dizajn i konstrukcione odlike neodvojivi su od odnosa između ljudi i predmeta. Meikis smatra da se taj odnos može tumačiti i kao niz afektivnih susreta koji proizvode želju shvaćenu kao skup predsvesnih socijalnih nagona i impulsa koji konstituišu motivacione sile odgovorne za oblikovanje pojedinačnih interesa. ${ }^{9}$ Meikis zastupa tezu o moći oružja da oblikuje želju za nasiljem, odnosno kako međudejstvo sa oružjem rađa emotivnu silu kao afektivnu moć da se čin nasilja učini ne samo legitimnim, nego i poželjnim. Reč je o, kako Meikis kaže, fenomenu weaponization of politics, koji opisuje socijalnu situaciju u kojoj oružje ne samo da koegzistira sa ljudima, nego postaje predmet brige i suštinsko obeležje političkog života. Oružje nije više samo provodnik ljudske sposobnosti da odlučuje po svojoj volji, nego postaje i svojevrstan delatnik (agent) sa formativnom moći stvaranja određenih tipova ljudskog ponašanja. Prema

\footnotetext{
${ }^{7}$ Ibid., pp. 563-564.

${ }^{8}$ Ibid., p. 557.

${ }^{9}$ Detaljniju argumentaciju videti u: Benjamin Meiches, "Weapons, desire, and the making of war", Critical Studies on Security, Vol. 5, Issue 1, 2017, pp. 9-27.
} 
Meikisu, oružje shvaćeno na ovaj način podstiče sekuritizaciju kao proces diskurzivne konstrukcije pretnji kroz razvoj novih oružanih sistema, i to tako što proizvodi forme želje koje čine mogućim nasilne društvene uslove. ${ }^{10}$

Uobičajena pretpostavka u pokušajima procene stepena i načina buduće zloupotrebe oružja, zasnovanog na naprednim tehnologijama, temelji se na jednodimenzionalnom očekivanju da će njegova raspoloživost nužno dovesti do povećane sklonosti za izvođenjem vojnih operacija, a time i do većih kolateralnih žrtava i materijalne štete. Kako to ne mora da bude nužan ishod uvođenja novih oružja, moja polazna pretpostavka biće usredsređena na to kako strukturne odlike nesmrtonosnog oružja mogu da oblikuju nove načine optimalnog ostvarenja spoljnopolitičkih interesa, uzeto na primeru SAD, tačnije načine na koje supersila može da tehnološke potencijale tog oružja preinači u potencijal za očuvanjem osporene globalne dominacije. Čitav proces preinačavanja čini pojedine nasilne prakse legitimnim i time poželjnim, a druge delegitimizuje i obezvređuje, i to tako što ih uklapa u novu logiku nasilja. U povratnoj sprezi, nova logika nasilja postepeno se uklapa u normativni okvir odvijanja ratnih operacija, odnosno oblikuje nove prihvatljive načine na koje se odigravaju smrt i ranjavanje. Pogledajmo sada, u kratkim crtama, koji je to međunarodni kontekst analize mogućih načina upotrebe dostignuća Četvrte industrijske revolucije ugrađenih $u$ nesmrtonosno oružje.

\section{Međunarodna arena $u$ ranom XXI veku kao početna pozicija primene nesmrtonosnog oružja}

Vojna intervencija SAD i njenih saveznika u Avganistanu predstavlja najduži američki rat, a njegov kraj se nazire posle dugotrajnih mirovnih pregovora okončanih potpisivanjem sporazuma sa predstavnicima talibana (februar 2020). ${ }^{11}$ Doduše, američki predsednik Donald Tramp (Donald J. Trump) obavezao se da ćeSAD i njegovi saveznici iz NATO povući trupe iz Avganistana samo ako u narednih 14 meseci talibani budu dokazali da poštuju odredbe mirovnog sporazuma. Imajući u vidu da tek slede komplikovani pregovori talibana sa vladom u Kabulu, sa neizvesnim

\footnotetext{
${ }^{10}$ Ibid., pp. 15-16.

11 "Afghan conflict: US and Taliban sign deal to end 18-year war", BBC News, 29

February 2020, https://www.bbc.com/news/world-asia-51689443, 12/03/2020.
} 
ishodom, nastavak vojne intervencije možda ipak ostane optimalna opcija za Vašington. Slična neizvesnost vlada i u slučaju američkog mešanja u građanski rat u Siriji. Ako uzmemo za istinitu misao austrijske pesnikinje Ingeborg Bahman (Ingeborg Bachmann), iskazanu u stihu njene poeme "Svaki dan" - da se rat više ne objavljuje nego samo nastavlja - onda se pokazuje smislenom i teza o beskrajnim ratovima koju razvija En Hironaka (Ann Hironaka). ${ }^{12}$ Tačnije, linija između rata i mira je sve više zamagljena. U beskrajnim vojnim intervencijama realno se pojavljuje problem kako proglasiti pobedu i povući se u okolnostima kada ne postoji politička volja da supersila prizna poraz nakon dugotrajnog i veoma skupog angažovanja, a bez konkretnog pozitivnog učinka koji bi opravdao njenu globalnu ulogu.

Rat protiv terora je, legitimizujući svoju beskrajnost kroz ciljeve smeštene u carstvo dobra i zla, reaktuelizovao imperijalnu civilizatorsku misiju SAD i njenih zapadnih saveznika isključujući neprijatelje iz moralne ravni (neo)liberalnog poretka kao kriminalce i otpadnike koji nisu vredni moralnih obzira. Marčelo Maneri (Marcello Maneri) nas podseća da je u godinama nakon 2001. godine oživljavanje metafora politike neprijateljstva iz vremena ranijih ratova sazdano na javnim ritualima komemoracija i oplakivanja stradalih ( $\mathrm{u}$ terorističkim napadima), i borbi za povratak $\mathrm{u}$ stanje bezbednosti, legitimisanoj na željama, mislima i rečima "običnog čoveka" kao oličenja karikaturalne slike normalnosti u vidu "normalnog građanina" ${ }^{13}$ Normalnost je uvek postavljena nasuprot „drugosti" koja postoji negde $\mathrm{u}$ spoljnom prostoru, a oličena je $\mathrm{u}$ demonskoj predstavi iracionalnosti i devijantnosti kao osnovnim osobinama neprijatelja opaženog kao preteća figura mučitelja "običnog čoveka” postindustrijskog društva.

Legitimizacija intervencionističke spoljne politike SAD i drugih zapadnih zemalja, u postkolonijalnom delu sveta, zasnovana je poslednje tri decenije na razlozima navodne odbrane civilizacijskih tekovina Zapada od tzv. odmetničkih država i raznorodnih nedržavnih aktera, koji osporavaju univerzalnu vrednost liberalnog poretka. Kako su vrednosno utemeljene $u$ konceptima međunarodnog društva, demokratskog mira i podele sveta na

${ }^{12}$ Ann Hironaka, Neverending wars: The international community, weak states, and the perpetuation of civil war, Harvard University Press, Cambridge (MA) \& London, 2005.

${ }^{13}$ Marcello Maneri, "Peacetime war discourse: The political economy of bellicose metaphors", in: Alessandro Dal Lago and Salvatore Palidda (eds), Conflict, Security and the Reshaping of Society: The Civilization of War, Routledge, Oxon \& New York, 2010, pp. 162-164. 
liberalan centar i „,necivilizovanu” periferiju, spoljne politike SAD i zapadnih sila prilagodile su asimetričan karakter oružanih sukoba s kraja XX i početka XXI veka potrebama svog spoljnopolitičkog instrumentarijuma i postepeno preobrazile ratovanje $\mathrm{u}$ politiku kontrole planetarne periferije. Kontrolna politika periferije uvela je metodologiju rada policije, krivičnog pravosuđa i kazneno-popravnog sistema u ontološku ravan vojnih intervencija, pa rat sada poprima obeležja politike borbe protiv kriminala. Za razliku od klasičnog doktrinarnog shvatanja prema kojem se rat vodi uglavnom radi osvajanja dela teritorije, potpune okupacije ili preuzimanja nacionalnih resursa neke države - dakle, materijalnih interesa obrazloženih konkretnim političkim ciljevima intervencionistička politika SAD i njenih saveznica u vidu disciplinskih ratova je svojevrsna pedagoška mera kako bi se prekršilac "popravio" i potom privoleo liberalnom moralno-vrednosnom i društvenom poretku. ${ }^{14}$

U prilog tome govori donekle i ideja o Imperiji koju su razvili Hart i Negri (Michael Hardt, Antonio Negri) kao središnju osu svoje čuvene konceptualizacije preobražaja suverenosti u doba globalizacije. Prema dvojici autora, Imperija kao međunarodni disciplinski poredak koji vlada današnjim međunarodnim odnosima obustavlja istoriju/istoričnost i sabira prošlost i budućnost unutar svog etičkog jezgra - predstavljenog svojstvima stalnosti, večnosti i neophodnosti. ${ }^{15}$ Imperija se ne nameće silom odozgo, već je ona prihvaćena u društvima Zapada posredstvom samodisciplinovanja samih stanovnika, tako da su oni sami odabrali uloge dobrih potrošača i dobrih građana. Ipak, Hart i Negri nas upozoravaju da benevolentnost Imperije iskazana u mobilisanju moći za humane ciljeve, nikako ne sme da nas zavara da ona kao međunarodni disciplinski poredak zapravo vlada kroz eksploataciju - samo manjina ima korist od iskorišćavanja celine kroz političke, ekonomske i društvene procese. ${ }^{16}$

Na upozorenja o eksploatativnosti Imperije naslanja se i stanovište Marka Niokliasa (Mark Neocleous) da zamagljena granica između rata i mira nije kontigentna, nego je sporedni proizvod jednog od najpopularnijih političkih mitova liberalizma ugrađenih $\mathrm{u}$ akademski diskurs o međunarodnim

${ }^{14}$ Opširnije obrazloženje teze o disciplinskim ratovima pogledati u: Srđan T. Korać, "Rat u 21. veku kao sredstvo imperijalne kontrole planetarne 'periferije'", Međunarodni problemi, vol. LXX, br. 4, 2018, str. 412-431.

${ }^{15}$ Michael Hardt and Antonio Negri, Empire, Harvard University Press, Cambridge (MA), 2000, pp. 11, 261.

${ }^{16}$ Ibid., p. 210. 
odnosima. ${ }^{17}$ Reč je o mitu proisteklom iz teze o demokratskom (liberalnom) miru, koji počiva na tvrdnji da je u prošlosti postojalo „klasično doba” u kojem je razlika između rata i mira bila smislena. Liberalna država postoji radi ostvarenja „liberalnog mira” unutar pojedinačnog građanskog društva, a posredstvom međunarodnog prava i na međudržavnom nivou. Prema tezi o liberalnom miru, rat je samo izuzetak; no, on je i nužno sredstvo sistematičnog nasilnog nametanja liberalnog mira, te prerasta $\mathrm{u}$, kako Nioklias lucidno primećuje, „nasilje liberalnog mira”. ${ }^{18}$ Kao što postoje višestruki stalni ili polustalni ratovi protiv "unutrašnjih neprijatelja” (npr. višedecenijski rat protiv droge u SAD) podstaknuti liberalnim „uslovnim refleksom" za pacifikovanjem nekooperativnih delova građanskog društva, tako je i na globalnom nivou liberalni večni mir kodifikovan kao pacifikacija radi bezbednosti. Da podsetimo, bezbednost je izdignuta na nivo vrhovnog koncepta buržoaskog društva.

Postvestfalski međunarodni sistem sa liberalnim demokratijama kao njegovim vodećim (i navodno, jedinim legitimnim) zastupnicima i subjektima vidi rat kao svojevrsnu regulatornu praksu, omeđenu međunarodnim pravom oružanih sukoba, odnosno kao tehnologiju vladavine usmerene na koreniti preobražaj "necivilizovanih" i "polucivilizovanih" društava, te samog međunarodnog sistema kao celine. ${ }^{19}$ Tako liberalna škola mišljenja i praksa omogućavaju legitimizaciju upotrebe oružane sile i pozive da se redizajnira pravosudna osnova međunarodnih odnosa, tako da prosvećene države i međunarodne organizacije mogu da preduzimaju vojne intervencije i radi sprečavanja realizacije neposredne pretnje po ljudska prava u bilo kom kutku planete. Na tragu razmišljanja Salvatorea Palide (Salvatore Palidda) o sunovratu socijalne uloge policije na nacionalnom nivou, smatram da se jednako može povući paralela sa destruktivnom kvazipolicijskom ulogom intervencionističkih snaga $\mathrm{u}$ disciplinskim ratovima XXI veka. ${ }^{20}$ Zasnovana na nultoj toleranciji prema

\footnotetext{
${ }^{17}$ Više o ovoj tezi videti u: Mark Neocleous, "War as peace, peace as pacification", Radical Philosophy, No. 159, January-February 2010, pp. 8-17.

${ }^{18}$ Ibid., p. 9.

${ }^{19}$ Detaljnije pogledati $\mathrm{u}$ : Vivienne Jabri, War and the Transformation of Global Politics, Palgrave Macmillan, Basingstoke \& New York, 2007, pp. 97-116.

${ }^{20}$ Salvatore Palidda, "Revolution in police affairs", in: Alessandro Dal Lago and Salvatore Palidda (eds), Conflict, Security and the Reshaping of Society: The Civilization of War, Routledge, Oxon \& New York, 2010, pp. 124-125.
} 
bilo kojoj vrsti aktivnosti koju opaža kao devijantnu, odnosno kao pobunu protiv liberalnog mira, politika disciplinovanja globalne periferije i dalje ne ulazi u društvene uzroke antiliberalnog "odmetništva" već podstiče beskonačno reprodukovanje povratne petlje između društvene zebnje, nebezbednosti i preterane sekuritizacije.

Rat kao disciplinski postupak ne tretira više neprijatelja kao pripadnika suparničke vojske koja se poštuje shodno univerzalnim načelima vojne etike i običajnog ratnog prava. Neprijateljski vojnik je sada običan kriminalac čije devijantno postupanje opravdava obezvređivanje njegove ličnosti kao pojedinca nedostojnog života u liberalnom poretku. Ipak, disciplinsko ratovanje podleže određenom stepenu pravne uređenosti i usklađenosti sa moralnim obzirima koji čine temelj prosvetiteljske misije (neo)liberalizma. Nekadašnji američki sekretar odbrane Donald Ramsfeld (Donald Rumsfeld) rekao je jednom prilikom da "smrt teži da ohrabri depresivno viđenje rata", pa ne čudi što SAD nastoje da svoje intervencije učine navodno humanim i očišćenim od tereta moralno pogrešnog postupanja prema civilima. ${ }^{21}$ Razvoj i primenu nesmrtonosnog oružja $u$ disciplinskim ratovima upravo treba sagledati kao korak ka daljoj sanitizaciji vojnih operacija u okviru kaznenih ekspedicija projektovanih na žarišta pobune globalne periferije protiv hartovsko-negrijevske Imperije. ${ }^{22}$ Praksa sanitizacije rata samo je još jedan napor politike supersile usmeren na osiguranje demokratske legitimizacije ratovanja u XXI veku posredstvom njegove glorifikacije i estetizacije. ${ }^{23}$

\section{Koje strukturne odlike čine nesmrtonosno oružje korisnim za vojne planere?}

Kako bi izgledao idealno sanitizovan rat? Pukovnik Džordž Fenton (George Fenton), direktor Uprave za nesmrtonosno oružje Korpusa mornaričke

${ }^{21}$ Roger Cohen, "Rumsfeld Is Correct - the Truth Will Get Out", The New York Times, 7 June 2006, https://archive.nytimes.com/www.nytimes.com/iht/2006/06/07/ world/IHT-07globalist.html?pagewanted=all, 18/03/2020.

${ }^{22}$ Više o konceptu sanitizacije rata u: Evren M. Eken, "Sanitization of War", in: Paul Joseph (ed.), The SAGE Encyclopedia of War: Social Science Perspectives, SAGE Publications Inc., Thousand Oaks (CA), 2017, pp. 1516-1517.

${ }^{23} \mathrm{O}$ isprepletanosti glorifikacije, estetizacije i sanitizacije rata danas videti u: Gregory Paschalidis, "Images of War and the War of Images", Gramma: Journal of Theory and Criticism, Vol. 7, 1999, pp. 121-152. 
pešadije SAD (US Marine Corps' Joint Non Lethal Weapon Directorate), osnovane 1996. godine odlukom Kongresa, jednom prilikom je izjavio da bi najradije voleo da postoji magični prah koji bi mogao da uspava neprijatelja i civile i da se tako izbegnu žrtve i ostvari borbeni zadatak. ${ }^{24}$ Zavodljiva naučnofantastična maštanja o magičnim sredstvima više su fantastična nego naučna, jer nisu u domašaju sadašnjih naučno-tehnoloških dostignuća. Ipak, pregled projekata konstrukcije novih vrsta oružja u SAD i Velikoj Britaniji, na kojima rade naučnici i inženjeri deceniju unazad, otkriva da je veliki deo inovacionih napora posvećen domišljanju troškovno prihvatljivih tehnološko-tehničkih proboja u razvoju nesmrtonosnog oružja. Primer uspešne konstrukcije nesmrtonosnog oružja je Gate-crasher - eksplozivna naprava za upade $\mathrm{u}$ objekte posredstvom usmerene eksplozije, gde se mala količina eksploziva koristi efikasno tako da napravi otvor tačno određene veličine, bez nepotrebnog razaranja i ljudskih žrtava. ${ }^{25}$

Nesmrtonosno oružje se određuje kao ono čija fizička svojstva i operativne karakteristike proizvode privremeno onesposobljavanje malog obima koje se može kasnije poništiti, odnosno ono nije namenjeno ubijanju ili prouzrokovanju trajnih (ireverzibilnih) povreda i sakaćenja, niti potpunom uništavanju civilne infrastrukture i životnog okruženja. ${ }^{26}$ Njegova osnovna namena je da pruži veću elastičnost upotrebe sile $u$ borbenim zadacima i veću brzinu odgovora na neprijateljska dejstva tako

${ }^{24}$ Navedeno prema: "Special Report Emerging Technologies and Their Impact on Arms Control and Non-Proliferation", NATO Parliamentary Assembly, 2001, https:/ / www.bits.de/NRANEU/BMD/documents/NATO-PA\%20New\%20Technologies. pdf, 29/03/2020.

${ }^{25}$ Navedeno prema: „, Oružje budućnosti”, Discovery Science HD, dokumentarna tv serija prikazana od 7. do 16. avgusta 2019, (Future Weapons, https://go.discovery.com/tvshows/future-weapons/).

${ }^{26}$ Kao sinonimni termini u anglo-američkoj naučnoj i stručnoj literaturi pojavljuju se i atributi soft-kill, less-than-lethal, sub-lethal. Dato pojmovno određenje predstavlja autorovu sintezu osnovnih elemenata definicija datih $\mathrm{u}$ : "Special Report Emerging Technologies and Their Impact on Arms Control and Non-Proliferation", op. cit.; "DoD Executive Agent for Non-Lethal Weapons (NLW), and NLW Policy", DoD Directive 3000.03E, US Department of Defense, 31 August 2018, https:/ / www.esd. whs.mil/Portals/54/Documents/DD/issuances/dodd/300003p.pdf?ver= 2018-1024-112944-467, 25/04/2020; Pauline Kaurin, "With Fear and Trembling: An Ethical Framework for Non-Lethal Weapons", Journal of Military Ethics, Vol. 9, No. 1, 2010, p. 102; Dane Subošić, Nesmrtonosno oružje, Novinsko-izdavački centar Vojska, Beograd, 2005. 
da neutrališe pretnje na bojištu bez pribegavanja smrtonosnoj sili. Nasuprot tome, operativna delotvornost konvencionalnog oružja je upravo određena njegovim potencijalom da prouzrokuje smrt. Sistemi nesmrtonosnog oružja mogu biti konstruisani kao samostalno oružje ili kao dodatak konvencionalnom oružju koji borcu pruža mogućnost da u zavisnosti od potreba konkretne borbene situacije odabere adekvatan stepen sa skale kontinuuma primene oružane sile. ${ }^{27}$ Takođe, nesmrtonosno oružje pruža mogućnost napada na jednu ili više meta istovremeno. ${ }^{28}$

Mada se konceptualno brojna nesmrtonosna oružja razvijaju već nekoliko decenija, pojedini autori, poput Jirgena Altmana (Jürgen Altmann), još pre dve decenije ukazivali su da tvrdnje o dostizanju održivih naprednih tehnoloških rešenja za nesmrtonosno oružje treba uvek uzimati sa rezervom, zato što je samo manji broj njih utemeljen na tačnim, pouzdanim i naučno validnim proverljivim dokazima. ${ }^{29}$ Trenutno je u upotrebi nesmrtonosna muncija $\mathrm{u}$ vidu npr. metaka slabe udarne moći (low-impact bullets), hemikalije za onesposobljavanje opreme (lepkovi, korozivi i sredstva za vlaženje) i ljudi (npr. suzavac), pene za imobilisanje osoba i opreme, naprave za zaustavljanje vozila (npr. mreže), akustični uređaji (npr. za proizvodnju usmerene buke) i optički uređaji za ometanje vida. ${ }^{30}$

Budući da su vojni razvojni projekti po pravilu poverljive prirode, čak i kada ih sprovode civilne kompanije i naučne organizacije, te da rezultati istraživanja i tehničke inovacije samim tim nisu dostupni javnosti, procene se mogu sačiniti na osnovu fundamentalnih znanja iz određene naučne oblasti. Američki vazduhoplovni pukovnik Džozef Siniskalči (Joseph Siniscalchi) je još krajem devedesetih godina XX veka analizirao kako raznolike napredne tehnologije, primenjene $\mathrm{u}$ konstrukciji nesmrtonosnog

27 "Less-lethal Weapons", Small Arms Survey, www.smallarmssurvey.org/weaponsand-markets/products/less-lethal-weapons.html, 20/04/2020.

28 "Current Intermediate Force Capabilities", U.S. Department of Defense, https:/ / jnlwp.defense.gov/Current-Intermediate-Force-Capabilities/.

${ }^{29}$ Opširnije o problemu pristupa javnosti dostignućima u oblasti razvoja nesmrtonosnog oružja videti u: Jürgen Altmann, "Non-lethal Weapons Technologies - The Case for Independent Scientific Analysis", Medicine, Conflict and Survival, Vol. 17, No. 3, 2001, pp. 234-247.

${ }^{30}$ Iscrpan prikaz razvoja nesmrtonosnog oružja dat je u: Neil Davison, "Non-Lethal" Weapons, Palgrave Macmillan, Basingstoke, 2009, pp. 12-104; “Current Intermediate Force Capabilities", op. cit. 
oružja, daju ovoj vrsti oružja specifične strukturne odlike, koje mu potom pridaju posebnu ulogu u vojnim strategijama i planovima. Reč je o pet sledećih obeležja:

- Preciznost - precizno navođena nesmrtonosna oružja imaju sposobnost kontrole stepena destruktivnosti tako što, za razliku od konvencionalnog oružja, napadaju samo pojedine komponente neprijateljske infrastrukture ili ljudstva;

- Radijus - nesmrtonosna oružja u načelu mogu imati daleko veći radijus borbenog dejstva, a u spoju sa minimalizacijom rizika od smrtnog ishoda po neprijatelja, radijus može biti daleko širi. Na taj način, nesmrtonosnim oružjem možemo da uništavamo neprijateljsku opremu čak i kada je raspršena na prostranom području, ili kada nije moguće tačno odrediti koje su ključne infrastrukturne tačke;

- Ponovljivost učinka - imajući u vidu stalni razvoj protivmera, pouzdanost nesmrtonosnog oružja u pogledu pružanja planiranog/ očekivanog borbenog učinka zasniva se prvenstveno na izvesnosti da će ono moći da ponovi taj učinak u različitim borbenim uslovima, odnosno čak i kada neprijatelj sprovodi protivmere;

- Selektivnost - svrha nesmrtonosnog oružja u vidu namere da se izbegnu ljudsko stradanje i materijalna šteta pruža mogućnost osmišljavanja i sprovođenja daleko fleksibilnijih spoljnopolitičkih i vojnih strategija i planova koji bi bili neodrživi kada bi se koristilo samo konvencionalno oružje;

- Sposobnost pariranja konvencionalnom oružju - budući razvoj trebalo bi da omogući i dalekometnost nesmrtonosnog oružja npr. uparivanjem sa projektilima i letelicama bez posade, čime bi se smanjio rizik od tzv. prijateljske vatre i stvorili preduslovi za dejstva po strateškim ciljevima. ${ }^{31}$

Program za razvoj nesmrtonosnog oružja Ministarstva odbrane SAD potekao je iz otrežnjujućeg iskustva intervencije u Somaliji, gde je general mornaričke pešadije Entoni Zini (Anthony Zinni) prvi taktički koristio policijsko oružje i municiju sa učinkom "manjim od smrtonosnog”, kako bi otvorio širi raspon tzv. opcija „između vikanja i pucanja” radi suzbijanja

${ }^{31}$ Joseph Siniscalchi, "Non-Lethal Technologies: Implications for Military Strategy", Occasional Paper No. 3, March 1998, Center for Strategy and Technology, Air War College, Air University, Montgomery, https://fas.org/man/dod-101/sys/land/ docs/occppr03.htm, 26/04/2020. 
otpora lokalnih boraca. ${ }^{32}$ Jednako je otrežnjujuća ocena pojedinih autora koji smatraju da američki Program za razvoj nesmrtonosnog oružja ni nakon više od dve decenije postojanja - te udruženog napora vojnih i privatnih razvojnih kapaciteta - nije uspeo da načini krupan pomak na planu razvoja održivog oružja te vrste sa stanovišta proizvodne cene i mogućnosti operativne primene. ${ }^{33}$ Do sada razvijeni modeli nesmrtonosnog oružja su skromnih mogućnosti, i to uz stalne godišnje sitne prepravke i dopune; modeli koji se nalaze $u$ fazi razvoja daleko su od operativne stvarnosti bojnog polja. Ipak, analiza načina trenutne ili buduće primenjivosti nesmrtonosnog oružja u disciplinskim ratovima XXI veka zahteva kratak pregled postignutog.

\section{Zvuk kao oružje}

Primena akustike $u$ razvoju nesmrtonosnog oružja započela je još sedamdesetih godina minulog veka i temelji se na učinku koji usmereno dejstvo velike akustične energije može da proizvede $u$ vidu dezorijentisanosti ili privremene nesposobnosti pojedinca ili grupe. ${ }^{34}$ Posledice zvučnih talasa po ljudski organizam su složene i zavise od primenjenih frekvencija, zvučnog pritiska i dužine izloženosti. Većina oružja ove vrste se konceptualno zasniva na upotrebi niskih (infrazvuk) ili veoma visokih frekvencija kako bi izazvala psihološke efekte, ali bez moždanih oštećenja. Upotreba infrazvuka bila bi zgodno oružje protiv ljudstva, zato što frekvencije niže od $20 \mathrm{~Hz}$ izazivaju dezorijentisanost, mučninu i grčeve u stomaku, koji mogu dovesti i do trajnih oštećenja i smrti.

Kineska vlada je 2019. godine objavila da je Tehnički institut za fiziku i hemiju Kineske akademije nauka uspeo da dizanira prenosivo sonično oružje sa usmerenim infrazvučnim talasima za razbijanje demonstracija,

\footnotetext{
32 "Non-Lethal Weapons Program Executive Agent's Planning Guidance 2016", U.S. Department of Defense, 2016, https://jnlwp.defense.gov/Portals/50/Documents/ Resources/Publications/Government_Reports/DoD_NLW_EA\%20_Planning_Guid ance.pdf, p. 2.

${ }^{33}$ Ofer Fridman, "Nonlethal Weapons: A Technological Gap or Misdefined Requirements?", Joint Force Quarterly, No. 76, January 2015, pp. 71-77; David A. Koplow, "Red-Teaming NLW: A Top Ten List of Criticisms About Non-Lethal Weapons", Case Western Reserve Journal of International Law, Vol. 47, 2015, p. 231.

${ }^{34}$ Neil Davison, "Non-Lethal" Weapons, op. cit., p. 186.
} 
koje izaziva krajnju nelagodnost usled vibracija u bubnim opnama, očnim jabučicama, stomaku i mozgu. ${ }^{35}$ Prototip je u fazi razvoja za masovnu proizvodnju. Magnetski audio uređaj (The Magnetic Audio Device - MAD), koji je razvila privatna kompanija iz Kalifornije HPV Technologies, odašilje usmereni talas zvuka na daljinu veću od jednog i po kilometra, a na kratkom rastojanju zvuk proizvodi bol. ${ }^{36}$ Naučnici i inženjeri nisu uspeli da zagospodare akustičnom energijom $u$ meri koja bi omogućila da privremeno onesposobe ljude, a da u isto vreme pouzdano uklone rizik od trajnog oštećenja njihovog sluha - pogotovo u visokofrekventnom delu spektra. ${ }^{37} \mathrm{U}$ prilog tome svedoče tvrdnje da izraelsko oružje tog tipa nazvano „Krik”, a korišćeno za razbijanje uličnih protesta, izaziva oštećenje unutrašnjeg dela uha i sluha. ${ }^{38}$

Američko ministarstvo odbrane trenutno razvija tehnologiju ugljeničnog nanocevnog termofona (Carbon Nanotube Thermophone) $\mathrm{u}$ vidu laganog akustičnog projektora koji stvara snažne zvučne talase naizmeničnim zagrevanjem i hlađenjem cevi od čistog sitno upletenog ugljenika. ${ }^{39}$ Američko ministarstvo odbrane planira da nesmrtonosno oružje ovog tipa instalira na male dronove koji bi se koristili pri hvatanju begunaca ili hapšenju. Takođe, još u fazi laboratorijskih ispitivanja, nalazi se i stvaranje efekta laserski indukovane plazme (Laser-Induced Plasma Effect). Prototip uređaja sastoji se od dva lasera: jedan laser pulsira usled brzog uključivanja i isključivanja i tako izmeštanjem elektrona u vazduhu stvara plazmu; drugi

${ }^{35}$ Stephen Chen, "Chinese scientists develop handheld sonic weapon for crowd control", The South China Morning Post, 19 september 2019, https:/ / www.scmp.com/ news/china/science/article/3028071/chinese-scientists-develop-handheld-sonicweapon-crowd-control, 27/04/2020.

${ }^{36}$ Internet prezentacija HPV Technologies: www.getmad.com/military; "Magnetic Audio Devices", www.zemos98.org/controlsonoro/wp-content/uploads/pdf/mad _web_entry_metric.pdf, 27/04/2020.

${ }^{37}$ Pregled istraživanja o mogućim dejstvima akustičnog oružja videti u: James R. Jauchem, Michael C. Cook, "High-Intensity Acoustics for Military Nonlethal Applications: A Lack of Useful Systems", Military Medicine, Vol. 172, Issue 2, 2007, pp. 182-189.

${ }^{38}$ Xeni Jardin, "Focused Sound 'Laser' for Crowd Control", NPR, 21 September 2005, https://www.npr.org/templates/story/story.php?storyId=4857417, 27/04/2020.

${ }^{39}$ Rebecca Heilweil, “The Ingredients Powering the DOD's New Nonlethal Weapons", Wired, 20 November 2018, https:/ / www.wired.com/story/ingredients-poweringdefense-department-new-nonlethal-weapons/, 27/04/2020. 
laser projektuje zrak tačno u prethodno stvoren oblak jonizovanog gasa i tako oslobađa zvučnu energiju u vidu ekstremno bučnog praska. ${ }^{40}$

Upotreba infrazvuka protiv infrastrukture ogledala bi se u slabljenju ili razaranju strukture metala, prouzrokovanju termalnih oštećenja i manjih lokalizovanih zemljotresa. Američka vojska tek razvija koncept prenosivog uređaja sa samostalnim napajanjem koji bi mogao da zaustavlja kretanje kopnenih vozila i plovila primenom radio frekvencija velike energije $\mathrm{u}$ mikrotalasnom spektru, tako što bi im prekinuo rad pogonskog motora dejstvom na elektronske komponente. ${ }^{41}$

\section{Usmerena energija kao oružje}

Razvoj oružja usmerene energije počeo je još osamdesetih godina XX veka $\mathrm{u}$ nastojanju da se stvori oružje koje bi bilo u stanju da proizvodi snop koncentrisane elektromagnetne energije $u$ različitim delovima njenog spektra, ili snop atomskih/subatomskih čestica, i oružje usmerene energije radi nanošenja štete ljudima, opremi i postrojenjima. ${ }^{42}$ Oružja usmerene energije obuhvataju lasere (sa dejstvom u vidljivom, infracrvenom ili ultraljubičastom delu spektra) i uređaje koji proizvode snopove radiotalasa, mikrotalasa i milimetarskih talasa (30-300 GHz). ${ }^{43}$ Osnovni cilj je postići ogromnu preciznost, sposobnost delovanja brzinom svetlosti i neograničene „municije”.

Sudeći prema podatku da je američko ministarstvo odbrane samo u periodu 2017-2019. udvostručilo budžetsku liniju za razvoj oružja usmerene energije, i to sa 535 miliona na 1,1 milijardu dolara, ova vrsta nesmrtonosnog oružja definitivno ima prioritet $u$ srednjoročnim istraživačko-razvojnim naporima. ${ }^{44}$

\footnotetext{
${ }^{40}$ Ibid.

41 "Radio-Frequency Vehicle Stopper", U.S. Department of Defense, https:/ /jnlwp. defense.gov/Future-Intermediate-Force-Capabilities/Radio-Frequency-VehicleStopper/, 21/04/2020; "Radio-Frequency Vessel Stopper", U.S. Department of Defense, https:/ /jnlwp.defense.gov/Future-Intermediate-Force-Capabilities/RadioFrequency-Vessel-Stopper/, 21/04/2020.

${ }^{42}$ Neil Davison, "Non-Lethal" Weapons, op. cit., p. 143.

43 "Directed Energy: Sound and Light Technology", U.S. Department of Defense, https:/ /jnlwp.defense.gov/Press-Room/Fact-Sheets/Article-View-Fact-sheets/ Article/1574157/directed-energy-sound-and-light-technology/, 21/04/2020.

${ }^{44}$ Shaun Waterman, "Directed Energy Weapons Move Closer to Prime Time", Air Force Magazine, 29 October 2019, https://www.airforcemag.com/directed-energyweapons-move-closer-to-prime-time/, 21/04/2020.
} 
Osnovni cilj je uspostaviti ravnotežu između bezbednosti i delotvornosti u pogledu kontrole zagrevanja i osigurati veliku snagu merenu stotinama kilovata. ${ }^{45} \mathrm{Na}$ primer, kada je reč o laserima i oružju zasnovanom na radio, milimetarskim i mikrotalasima, američki vojni planeri nastoje da proizvedu oružje sa operativnim sposobnostima koje neće oštetiti vid ili tkivo neprijateljskih vojnika u slučaju predugog izlaganja zračenju. ${ }^{46}$ Američko ministarstvo odbrane je septembra 2019. godine najavilo da će se usredsrediti na konstruisanje oružja usmerene energije koja će se lakše brzo razviti do nivoa isplative masovne proizvodnje, poput lasera visoke energije. ${ }^{47}$ Primer te vrste oružja u pripremi je HELIOS (High Energy Laser and Integrated Optical-dazzler with Surveillance), koji ratna mornarica SAD namerava da 2021. godine instalira na jednom od razarača, a opremljen je sposobnošću progorevanja trupa manjeg broda i obaranja bespilotnih letelica. Pored HELIOS-a, deo buduće porodice laserskih sistema u američkoj ratnoj mornarici (Navy Laser Family of Systems - NLFoS) činiće još dva sistema oružja usmerene energije: 1) SSL-TM (Solid State Laser-Technology Maturation system) predviđen za primenu na amfibijskim brodovima i; 2) ODIN (Optical Dazzling Interdictor, Navy) predviđen za razarače. ${ }^{48}$

Tehnologija aktivnog odbijanja (Active Denial Technology) je sposobnost da se dejstvuje na ljude proizvodnjom osećaja vreline posredstvom usmerenog milimetarskog zraka koncentrisane energije frekvencije $95 \mathrm{GHz}$ koji se na metu projektuje brzinom svetlosti. ${ }^{9}$ Zrak probija površinski sloj kože do dubine od nekoliko milimetara i stvara osećaj nepodnošljive vreline i okida instinktivnu reakciju mete da se pomeri sa tog mesta.

${ }^{45}$ Do sada je postignuta snaga tek od nekoliko desetina kilovata.

${ }^{46}$ Neil Davison, "Non-Lethal" Weapons, op. cit., pp. 210-211.

${ }^{47}$ Ben Werner, "Pentagon Shifts Focus on Directed Energy Weapons Technology", US Naval Institute Newss, 5 September 2019, https://news.usni.org/2019/09/05/ pentagon-shifts-focus-on-directed-energy-weapons-technology, 21/04/2020.

${ }^{48}$ Megan Eckstein, "Navy to Field High-Energy Laser Weapon, Laser Dazzler on Ships This Year as Development Continues", US Naval Institute News, 30 May 2019, https://news.usni.org/2019/05/30/navy-to-field-high-energy-laser-weapon-laserdazzler-on-ships-this-year-as-development-continues

${ }^{49}$ Susan LeVine, "The Active Denial System A Revolutionary, Non-lethal Weapon for Today's Battlefield", Center for Technology and National Security Policy, National Defense University, June 2009, https:/ /ndupress.ndu.edu/ Portals/68/Documents/ DefenseTechnologyPapers/DTP-065.pdf?ver=2017-06-22-143022-030, 21/04/2020; "Active Denial Technology", U.S. Department of Defense, May 2016, https://jnlwp. defense.gov/Press-Room/Fact-Sheets / Article-View-Fact-sheets / Article/ 577989/active-denial-technology/, 21/04/2020. 
Nakon dve decenije intenzivnog rada na konstrukciji oružja zasnovanog na stroboskopskom svetlu, odnosno snažnim pulsirajućim usmerenim svetlosnim zracima različitih frekvencija, sličan proizvod kompanije Peak Beam Systems našao je primenu na kupolama oklopnih vozila američke vojske. Reč je o uređaju koji projektuje usmereno stroboskopsko svetlo na daljinu od 150 metara i izaziva dezorijentisanost, ošamućenost i mučninu, čime se kod neprijatelja osujećuje sposobnost efikasnog nišanjenja i pogađanja meta, a posredno smanjuje ukupna borbena delotvornost tokom jedne taktičke operacije. ${ }^{50}$ Ruska vojska je početkom 2019. godine objavila da je na dve fregate instalirala uređaj za vizuelno optičko ometanje Filin 5P-42, koji projektuje zaslepljujući usmereni svetlosni zrak poput stroboskopskog svetla na daljinu veću od četiri kilometra. ${ }^{51}$ Filin $5 P-42$ može da značajno smanji učinak tehnologije noćnog osmatranja, sistema za lasersko nišanjenje, nišanjenja kod pešadijskog naoružanja i protivtenkovskih projektila.

\section{Biohemijski i hemijski agensi kao oružje}

Za razliku od međunarodnopravne zabrane upotrebe biološkog i hemijskog oružja u ratu, političke i naučno-tehnološke okolnosti doprinele su nesmetanom razvoju biološkog i hemijskog nesmrtonosnog oružja. Kada je reč o biohemijskim agensima, razvoj narkotika i ostalih psihoaktivnih supstanci sa onesposobljavajućim dejstvom na ljudski organizam poznat je još od pedesetih godina XX veka; npr. u vidu hemikalija koje prouzrokuju različite vidove iritacija, ili pak imaju dejstvo na ljudski organizam u rasponu od nesvesti do halucinacija. ${ }^{52}$ Iz ugla zahteva vojne primene, biohemijski agensi su u komparativnoj prednosti zato što su logistički održivi (dovoljne su neznatne količine), visoko potentni (brzo se šire i proizvode jaku čulnu iritaciju), značajno menjaju regulatornu aktivnost

\footnotetext{
${ }^{50}$ David Hambling, "The Long, Weird History of Strobe Weapons", Popular Mechanics, 11 February 2019, https://www.popularmechanics.com/military/weapons/ a26253652/history-strobe-weapons/, 22/04/2020.

${ }^{51}$ Callum Paton, "Filin: Russian Navy Unveils New Weapon That Makes Enemy Hallucinate, Vomit", Newsweek, 4 February 2019, https:/ / www.newsweek.com/filinrussian-navy-unveils-new-weapon-makes-enemy-hallucinate-vomit-1316545, 22/04/2020.

${ }^{52}$ Nonlethal Weapons and Capabilities, Council on Foreign Relations, New York, 2004, pp. 30-37; Neil Davison, "Non-Lethal" Weapons, op. cit., pp. 105-142.
} 
centralnog nervnog sistema, njihovo dejstvo traje satima i čak više dana i ne prouzrokuju trajna oštećenja organizma. ${ }^{53} \mathrm{U}$ američkoj vojsci je trenutno u upotrebi Oleoresin Capsicum dizajniran za kontrolu kretanja pojedinaca i grupa u određenoj zoni tako što se iz ručnog dispenzera raspršuje iritirajuća hemikalija $u$ vidu mlaza ili stvaranjem oblaka. ${ }^{54}$ Potencijalne mogućnosti unapređenja delotvornosti ove vrste nesmrtonosnog oružja pratiće produbljavanje shvatanja biohemijskih procesa u ljudskom organizmu na molekularnom nivou. ${ }^{55}$

U fazi razvoja se nalazi održiva primena hemijskih agenasa radi uništavanja optike ili ključnih delova oružja ili hemikalija koje nagrizaju gume na točkovima vozila, ili tečnog metala koji može učiniti krhkim druge vrste metala promenom njegove molekularne strukture.$^{56}$ Primera radi, adhezivni agensi su polimerne pene koje se brzo formiraju u prostoru, služe za zaustavljanje mete i zahtevaju specijalne rastvore za uklanjanje. Kontaminatori su aditivi koji dovode gorivo u želatinasto ili čvrsto stanje, superkaustici su kiseline koje daleko snažnije nagrizaju materijale, a lubrikanti supstance koje raspršene iz vazduha mogu da prouzrokuju gubitak trenja na putevima i železničkim prugama.

Upotreba genetskog inženjeringa radi manipulacije prirodnim procesima degradacije posredstvom mikroba omogućila je nova polja razvoja nesmrtonosnog biohemijskog oružja koje razara materijale. Biodeteriorativni mikrobi mogu da stvaranjem svojevrsnih „,̌̌epova” unutar mehaničkih sistema zaustave rad mašina, oštete ili razgrade gumu, plastiku

${ }^{53}$ Detaljnije u: Ronald G. Sutherland, "Chemical and Biochemical Non-lethal Weapons: Political and Technical Aspects", SIPRI Policy Paper No. 23, Stockholm International Peace Research Institute, November 2008, https://www.sipri.org/sites/default/ files/files/PP/SIPRIPP23.pdf, 23/04/2020, pp. 12-25.

54 "Oleoresin Capsicum Dispensers", U.S. Department of Defense, https://jnlwp. defense.gov/Current-Intermediate-Force-Capabilities/Oleoresin-CapsicumDispensers/, 23/04/2020.

55 Tom Burghardt, "Pentagon "Calmatives": Biochemical Substances as Incapacitating Weapons of War and Social Control", Global Research, Centre for Research on Globalization, 12 July 2008, https:/ / www.globalresearch.ca/ pentagon-calmativesbiochemical-substances-as-incapacitating-weapons-of-war-and-social-control/9573, 23/04/2020.

${ }^{56}$ Jürgen Altmann, "Non-Lethal Weapons Technologies: The Case for Independent Scientific Analysis", in: Nick Lewer (ed.), The Future of Non-Lethal Weapons: Technologies, Operations, Ethics and Law, Frank Cass Publishers, London, 2002, pp. 115-116. 
i kompozitne materijale, cementni ili asfaltni sloj puta ili mosta, pretvore gorivo u žele i da hemijski razgrade eksploziv ili čak metal. ${ }^{57}$

\section{Da li je nesmrtonosno oružje budući „magični prah" disciplinskih ratova?}

Važan strateški dokument vojske SAD posvećen opštim smernicama za razvoj oružanih snaga spram budućeg operativnog okruženja - Krovni koncept združenog delovanja (Capstone Concept for Joint Operations: Joint Force 2020) - jasno naglašava da neželjena kolateralna šteta u vidu civilnih žrtava i materijalne štete mora biti svedena na najmanju moguću meru, kako se ne bi dalje kompromitovalo spoljnopolitičko delovanje SAD, te da je jedan od načina njenog postizanja upotreba nesmrtonosnog oružja. ${ }^{58}$ Nasuprot tome, pojedini istraživači, poput npr. Dejvida Koplova (David A. Koplow), skeptični su u pogledu pojave velike potražnje za nesmrtonosnim oružjem u skorijoj budućnosti, jer strukturne odlike te vrste oružja nude rešenja za skoro nepostojeći problem, budući da se delotvorne ratne operacije i dalje ne mogu zamisliti bez ubijanja i razaranja. ${ }^{59}$ Ipak, premda su, uprkos dugotrajnosti, istraživanja i razvoj nesmrtonosnog oružja zaista do sada dali manje održivih konstrukcionih rešenja nego što je to obično slučaj, naredne godine i decenije XXI veka, usled naprednih tehnologija Četvrte industrijske revolucije, najverovatnije će omogućiti uvođenje pojedinih vrsta nesmrtonosnog oružja u oružane snage SAD. Zbog toga ću sada sagledati različite načine na koje bi tehnološki potencijal nesmrtonosnog oružja mogao da ga preporuči kao optimalno sredstvo imperijalnih kaznenih ekspedicija, imajući u vidu kontekst u kojem se odigrava tipična vojna intervencija na globalnoj periferiji.

Neregularan oružani otpor u spoju sa povremenim, sporadičnim borbenim ili drugačijim akcijama dela lokalnog civilnog stanovništa prvo je

57 "Non-Lethal Weapons Research in the US: Genetically Engineered Anti-Material Weapons", Backgrounder Series \#9, The Sunshine Project, March 2002, https:/ / target edindividualscanada.files.wordpress.com/2010/06/non-lethal-weapons-researchin-the-us-2002.pdf, 27/04/2020.

58 "Capstone Concept for Joint Operations: Joint Force 2020", Joint Chiefs of Staff, 10 September 2012, https:/ / ia801305.us.archive.org/14/items/Capstone-Concept-forJoint-Operations --Joint-Force-2020/Capstone \% 20Concept $\%$ 20for \% 20Joint \% 20Operations\%20-\%20Joint\%20Force\%202020.pdf, 27/04/2020.

${ }^{59}$ David A. Koplow, "Red-Teaming NLW: A Top Ten List of Criticisms About NonLethal Weapons", op. cit., p. 232. 
obeležje konteksta disciplinskog ratovanja na globalnoj periferiji. Gerilski način ratovanja - jedini istorijski potvrđen delotvoran odgovor na kaznene ekspedicije velikih sila, iznova otvara problem srazmernosti oružanog delovanja u kontekstu cilja uništenja pobunjeničkih snaga, jer se pred silom koja interveniše postavlja pitanje kako pronaći i uništiti odlučujući deo gerilske organizacije, a da se pri tome ne prouzrokuje preterano stradanje civila i ne ošteti njihova, obično skromna imovina. Koliko god da kvalitetne obaveštajne analize mogu da osiguraju pouzdane geografske koordinate meta vojnih udara, snaga gerilskog načina ratovanja ipak prevashodno počiva u volji lokalnog stanovništva da na različite načine bespogovorno podrži gerilske borce (finansijski, materijalno, logistički, regrutacijom, pružanjem obaveštajnih podataka o intervencionističkim trupama itd). ${ }^{60}$ Sudar odlučnog lokalnog otpora i nadmoćnih intervenišućih trupa bi u slučaju borbene upotrebe konvencionalnog oružja prouzrokovao obim ljudskih žrtava i štetu koji bi bili vidljivi i pogodni za medijsku eksploataciju, što bi dodatno odmoglo demokratskoj legitimizaciji nastavka vojnih operacija.

Postojanje čvrste volje lokalnog stanovništva da podrži gerilske operacije stoga neizbežno otvara pitanje postizanja većeg stepena poštovanja načela srazmernosti u disciplinskim ratovima XXI veka prosuđivanjem kako ostvariti suptilnu ravnotežu između ciljeva vojnih operacija, snage neprijateljskih trupa i verovatnoće prouzrokovanja civilnih žrtava i materijalne štete. Pored kvalitetne obaveštajne slike, kao osnove osmišljavanja i sprovođenja ratnih operacija na tuđoj teritoriji, pojedini autori za rešavanje problema nesrazmernosti u savremenim vojnim intervencijama preporučuju asimetrične psihološke operacije (Psychological Operations PSYOPs) i informacione operacije, kako bi se lokalno stanovništvo pružanjem valjane argumentacije zasnovane na pouzdanim informacijama ubedilo da je podrška intervencionističkim trupama u njihovom interesu. ${ }^{61}$ Bez uspostavljanja saradnje sa lokalnom političkom zajednicom i međusobnog poverenja, odnosno bez ukotvljavanja disciplinske akcije $u$ pristanak onih koje treba "disciplinovati”, vojne intervencije nikada neće moći da ostvare krajnji cilj izgradnje liberalnog poretka. To uostalom nedvosmisleno pokazuju ishodi „,beskrajnih” ratova vođenih u Avganistanu

${ }^{60}$ Michael L. Gross, "Asymmetric war, symmetrical intentions: Killing civilians in modern armed conflict", Global Crime, Vol. 10, No. 4, November 2009, p. 334.

${ }^{61}$ Adam D.M. Svendsen, "Strategy and Disproportionality in Contemporary Conflicts", Journal of Strategic Studies, Vol. 33, No. 3, June 2010, pp. 388-394. 
i Iraku. Mala verovatnoća pridobijanja kritičnog dela lokalnog stanovništva psihološkim i informacionim operacijama upućuje vojne planere da usredsrede razvojne potencijale na poštovanje načela srazmernosti optimalnim izborom tehnoloških dostignuća u okviru Četvrte industrijske revolucije koja doprinose "civilizovanju” ratnih operacija putem veće preciznosti ali $i, u$ isto vreme, ograničene upotrebe oružane sile.

Pitanje srazmernosti nas upućuje na urbano okruženje kao drugo obeležje konteksta disciplinskog ratovanja na globalnoj periferiji, budući da su gradovi oduvek upravna i privredna središta društvenog uticaja i bogatstva i da je migracija iz ruralnih u urbana područja postojan trend. Izvođenje borbenih operacija u gradskom tkivu podleže potpuno drugačijim taktičkim zahtevima nego što je slučaj kod konvencionalno definisanog vojišta u otvorenom krajoliku. Gusto naseljena gradska sredina pretpostavlja veći broj raznolikih aktera na strani neprijatelja (male terorističke grupe, kriminalne grupe, gerila, plemenske ili klanovske milicije), nejasnu liniju razdvajanja i time greške $u$ vidu dejstva po sopstvenim trupama, lakše kretanje/skrivanje neprijateljskih snaga, te usporavanje, okruživanje i iscrpljivanje intervenišućih trupa brojnim sitnim okršajima i prepadima. Predstavljene operativno relevantne strukturne odlike nesmrtonosnog oružja, posebno u vidu preciznosti, radijusa i selektivnosti, uklapaju se savršeno sa strukturnim obeležjima urbane sredine kao omiljenog vojišta za gerilske borce. Osnovna prednost tehnološkog potencijala nesmrtonosnog oružja je lakša kontrola nanošenja ljudskih žrtava i materijalne štete, što se odlično podudara sa strateškim i operativnim zahtevima izvođenja borbenih zadataka u urbanom okruženju. Reč je o tome da će lakše biti obnovljene vitalne javne usluge i infrastruktura, što će minimalizovati ometanje normalnog života lokalnog stanovništva. Otežano ili skoro nemoguće razlikovanje boraca i lokalnih žitelja - i što je jednako važno, razlikovanje borbenih i civilnih materijalnih resursa - uslovljava snažnu potrebu da se borbene operacije vode tako da se $\mathrm{u}$ što većoj mogućoj meri izbegnu civilne žrtve i materijalna razaranja privatne imovine i javne infrastrukture, što znači da bi nesmrtonosno oružje bilo prikladno sredstvo za izvođenje munjevitih i kratkotrajnih borbenih zadataka poput policijskih, kako bi se izbegla iritacija civila a istovremeno neutralisale neprijateljske jedinice. ${ }^{62}$

${ }^{62}$ Gerrard Quille, "The revolution in military affairs debate and non-lethal weapons", Medicine, Conflict and Survival, Vol. 17, No. 3, 2001, pp. 217-218. 
Shodno logici izvođenja kaznenih ekspedicija, nesmrtonosno oružje se u potpunosti podudara sa reprodukovanjem policijske strategije upravljanja rizicima od društvenog nereda i represivnog delovanja prema odmetničkim grupama koje podrivaju liberalni poredak..$^{63} \mathrm{Za} \mathrm{razliku} \mathrm{od} \mathrm{konvencionalnog}$ oružja koje ima binarnu opciju - pokušaj da ubiješ ili ne čini ništa, nesmrtonosno oružje nudi mogućnosti prilagođene opšteprihvaćenim pravilima vođenja savremenog rata, koje su usmerene na smanjenje obima nepotrebnih odnosno nenameravanih žrtava i materijalne štete. Iskustva komandira sa terena stečena $u$ mirovnim operacijama i vojnim intervencijama jasno su pokazala potrebu za bržim razvojem nesmrtonosnog oružja kako bi se što delotvornije prevazišao frustrirajući jaz između nečinjenja i ubijanja, kao mogućih izbora na skali borbenog dejstva. ${ }^{64}$ Utoliko se hibridizacija klasičnog policijskog rada i vojne operatike i taktike ogleda upravo u nameri da se gerilski borci ili pobunjenici samo privremeno onesposobe, kao i bilo koji drugi kriminalci, a potom uvedu $\mathrm{u}$ pravne okvire liberalnog poretka kroz krivični postupak.

Sadašnja generacija nesmrtonosnog oružja prvi put je taktički isprobana $\mathrm{u}$ američkim intervencijama u Somaliji, Iraku, Avganistanu i na Kosovu i Metohiji. Čak i kada bude dostiglo napredni stepen razvijenosti i održivosti u pogledu troškova proizvodnje, ovo oružje će verovatno uvek biti korišćeno u spoju sa konvencionalnim oružjem kao svojevrsna dopuna oružane sile (force multiplier), odnosno kao prethodnica upotrebe konvencionalnog oružja koja treba da snizi nivo borbene sposobnosti neprijatelja. Pred vojne planere opravdano se postavlja pitanje da li će nesmrtonosno oružje moći isključivo da služi kao sredstvo odvraćanja neprijatelja od daljeg razvijanja napada, i u kojim okolnostima trupe mogu da pređu sa upotrebe nesmrtonosnog na konvencionalno oružje i obratno. Kako dosadašnja praksa vojnih intervencija pokazuje, najsloženiji problem $\mathrm{u}$ hibridnom načinu upotrebe konvencionalnog i nesmrtonosnog oružja predstavlja brzina procene i odluke borca o tome da li situacija u kojoj se nalazi zahteva upotrebu jednog ili drugog oružja, odnosno da li mu je život

${ }^{63}$ Ovde se naslanjam na Delezovu dopunu Fukoovih teorijskih razmatranja o suverenim društvima kažnjavanja i discipline $u$ vidu tvrdnje da posle Drugog svetskog rata kontrola postaje daleko elastičniji način nadzora društva. Opširnije u: Gilles Deleuze, Postscript on the Societies of Control, MIT Press, Cambridge (MA), 1992. ${ }^{64}$ John B. Alexander, "An overview of the future of non-lethal weapons", Medicine, Conflict and Survival, Vol. 17, No. 3, 2001, p. 183. 
ugrožen ili nije. ${ }^{65}$ Na primer, odluka o izboru neposredno zavisi od kritične sposobnosti ispravne procene da li nepoznato vozilo koje se brzo približava kontrolnom punktu, ili nailazi na vojni konvoj, predstavlja pokretnu bombu ili njegov vozač jednostavno nije shvatio signale da treba da uspori. Utoliko je očigledno da upotreba nesmrtonosnog ne smanjuje opravdanost upotrebe konvencionalnog oružja; tačnije, prvo je jedino delotvorno kao dopuna, a nikako kao zamena za drugo. Primera radi, napad neprijateljskog snajperiste moguće je samo privremeno ometati npr. nekim oružjem usmerene energije, ali jedino protivsnajperska vatra konvencionalnim oružjem može da trajno ukloni bezbednosnu pretnju.

Asimetričnost vojne moći i, sledstveno, posedovanja naprednih vojnih tehnologija, može takođe da se pojavi kao potencijalan problem na planu strateške i operativne održivosti primene nesmrtonosnog oružja $u$ disciplinskim ratovima. Teško da će siromašne zemlje ili raznoliki poddržavni i/ili ratujući entiteti moći da odgovore srazmerno nesmrtonosnom napadu. Veća je verovatnoća da će posegnuti za konvencionalnim oružjem i podstaći eskalaciju sukoba, te time učiniti nesmrtonosno oružje izlišnim. Zato se $u$ raspravama američkih vojnih planera pojavila ideja o strateškoj upotrebi nesmrtonosnog oružja zasnovanog na biohemijskim i hemijskim agensima za povećanje ranjivosti ratnih kapaciteta i operativnih oružanih snaga neprijatelja, i to uništavanjem sistema ranog upozoravanja i komunikacione infrastrukture, ometanjem linija snabdevanja ili imobilizacijom opreme ${ }^{66} \mathrm{Na}$ taj način, nesmrtonosno oružje, uz odgovarajuću podršku verodostojne konvencionalne oružane pretnje, može da posluži kao delotvorno sredstvo prisile. Doduše, navedeno bi bilo ostvarivo samo pod pretpostavkom da je neprijatelj racionalan akter. To često nije slučaj kod ratujućih entiteta čiji su ciljevi delovanja maksimalizovani svojom eshatološkom prirodom, budući da su „sakralizovani" neposrednim pozivanjem na verska i ideološka učenja.

Strukturne odlike nesmrtonosnog oružja uslovljavaju nove načine na koje SAD može da tehnološke potencijale tog oružja preinači u potencijal

${ }^{65}$ Ben Lagasca, Susan LeVine and Brian Long, “Combatant or Collateral Damage? New Technology Offers Urban Ops Advantage", Army, August 2015, https://jnlwp. defense.gov/Portals/50/Documents/Resources/Publications/ Journal_Articles/ New_Technology_Offers_Urban_Ops_Advantage.pdf, pp. 25-27.

${ }^{66}$ Joseph Siniscalchi, "Non-Lethal Technologies: Implications for Military Strategy", op. cit. 
za očuvanjem globalne dominacije, koji će verovatno postepeno opadati u nastavku XXI veka usled jačanja globalnog uticaja Kine kao velike sile u usponu, te promenljive kooperativnosti pojedinih regionalnih sila. Čini se, da bi preinačavanje tehnološkog potencijala nesmrtonosnog oružja podstaklo šire uvođenje represivnih policijskih praksi kontrole stanovništva $\mathrm{u}$ vojni instrumentarijum disciplinskih ratova, te bi ih učinilo legitimnom komponentom nove ontologije nasilja $u$ međunarodnim odnosima XXI veka. Strukturne odlike nesmrtonosnog oružja, ispravno primenjene, idealno se uklapaju u normativni okvir odvijanja ratnih operacija u delu koji propisuje prihvatljive načine onesposobljavanja neprijateljskih vojnika za dalju borbu. Reč je prvenstveno o benignim intervencijama na telu koje ova vrsta oružja čini, pri čemu je benignost poželjno svojstvo oružja zato što se stara o očuvanju svetosti tela i ljudskog života. Time veština srazmernog borbenog dejstva, proistekla iz samog dizajna, konstituiše nesmrtonosno oružje unutar savremenog moralnog okvira vođenja rata, te služi kao važna vrednosno-normativna potpora demokratske legitimizacije vođenja disciplinskih ratova radi očuvanja liberalnog mira.

Dostizanje efikasnosti upotrebe nesmrtonosnih oružja usmerenih na ljude označila bi sposobnost kontrole stepena destruktivnosti i tako otvorila brojne mogućnosti ograničavanja štete i patnje nedužnih ljudi, a istovremeno bi vojnim planerima pružila precizniji instrument borbene sile sa velikim opsegom dejstva i minimalnim greškama prilikom razvrstavanja boraca od neboraca. Nesmrtonosno oružje omogućava sofisticiranije projektovanje najmanjeg nivoa upotrebe sile prilagođenog procenjenom stepenu vojne pretnje, te lakšem donošenju odluke o primeni taktike „prvo pucaj a posle pitaj”. Uzmimo hipotetički slučaj potrebe za brzim sprovođenjem disciplinske vojne ekspedicije protiv tehnološki zaostalog ratujućeg entiteta malog obima na udaljenom i nepristupačnom području globalne periferije, koji npr. ometa važnu saobraćajnu komunikaciju kojom se obavlja međunarodna trgovina, ili ugrožava eksploataciju prirodnih resursa od interesa za SAD. Iskrcavanje i kopneno angažovanje vojnih trupa na takvoj neprijateljskoj teritoriji zahtevalo bi ne samo preduzimanje složenog zahvata u ravni operatike i taktike - sa potencijalnim teškoćama koje bi nastale usled neizvesne dužine trajanja ekspedicije, nego i dugačak proces legitimizacije pred američkim javnim mnjenjem i unutar globalnih institucija (prevashodno Ujedinjenih nacija), solidno utemeljene na međunarodnopravnim i moralnim normama. Primenom odgovarajućeg nesmrtonosnog oružja sa velikim radijusom borbenog dejstva - npr. u spoju 
sa robotizovanim letelicama - ekspediciona disciplinska operacija mogla bi prvenstveno da bude usredsređena na kritično onesposobljavanje mehanizacije ili nanošenje štete drugim materijalnim resursima u posedu ratujućeg entiteta, a bez rizika od stradanja sopstvenih vojnika i sa minimalnim rizikom od uništavanja sopstvene vojne opreme. Na primer, ako ratujući entitet finansira svoje oružane aktivnosti uzgajanjem biljaka koje se koriste za proizvodnju narkotika, robotizovane letelice bi mogle da primene biološke ili hemijske agense i unište zasade, te tako nanesu kritičnu štetu njegovom „budžetu”. Takođe, primena ovih hemijskih agenasa mogla bi da onesposobi vozila kojima se pobunjenici transportuju kada izvode oružana dejstva, pa čak i njihovo naoružanje. Upotreba nesmrtonosnog oružja protiv neprijateljske borbene opreme verovatno bi uklonila potrebu za napornom demokratskom legitimizacijom tako osmišljene kaznene ekspedicije, budući da bi ulog u pogledu očekivanih budžetskih troškova na sopstvenoj strani bio prihvatljiv, a ne bi stradalo ni ljudstvo niti lokalno civilno stanovništvo. Na taj način izvedena vojna operacija verovatno ne bi ni izazvala veliku medijsku pažnju, što bi dodatno poboljšalo izglede za njenom (spoljno)političkom održivošću.

Razmotrimo sada ukratko verziju iste hipotetičke kaznene ekspedicije kada bi bilo primenjeno nesmrtonosno oružje namenjeno privremenom i kratkotrajnom onesposobljavanju ljudstva. Pretpostavimo da je dejstvo po materijalnim resursima razbesnelo vođe i pripadnike ratujućeg entiteta i ojačalo ih u uverenju da treba uzvratiti odmazdom $u$ vidu potpune blokade saobraćajne komunikacije kojom se obavlja međunarodna trgovina ili rušenjem postrojenja za eksploataciju prirodnih resursa. Robotizovane letelice bi - opskrbljene detaljnim podacima o kretanju pripadnika ratujućeg entiteta dobijenim satelitskim nadzorom $u$ realnom vremenu - mogle da po neprijateljskim jedinicama dejstvuju npr. biohemijskim agensima (radi izazivanja različitih vidova iritacija ljudskog organizma), akustičnim snopovima ili stroboskopskim svetlosnim snopovima (radi izazivanja dezorijentacije i mučnine), ili tzv. tehnologijom aktivnog odbijanja (radi stvaranja osećaja vreline). Ma koliko učinak po organizam neprijatelja bio kratkotrajan, odnosno reverzibilan, mišljenja sam da bi ove vrste nesmrtonosnog oružja imale značajan dugoročan psihološki učinak. Ovde valja pribeći imaginaciji. Zamislimo kako bi tehnološki zaostao neprijatelj misaono obradio i emotivno proživeo traumu izazvanu bilo kojim od prethodno nabrojanih efekata (npr. da iznenada oseti neizdrživu vrućinu ili ugleda zaslepljujuće svetlo), a bez jasne percepcije izvora ili uzroka tih 
efekata. Nesmrtonosno oružje bi u ulozi psihološkog oružja moglo da izazove iskonski strah od nepoznatog, zajednički svim ljudima bez obzira na sposobnost razumevanja kauzalnih odnosa (oružje-povreda), te da uznemiri pripadnike ratujućeg entiteta. Kada neprijatelju usadimo strah, imamo moć nad njim i možemo da ga nateramo da odustane od borbe.

Analizirane operativne karakteristike čine nesmrtonosno oružje prihvatljivim spram opšteprihvaćenih moralnih svetonazora i društvenih konvencija o prikladnosti i neprikladnosti pojedinih sredstava nasilja. Reverzibilnost posledica dejstva čini da nesmrtonosno oružje oblikuje prihvatljive načine na koje bi nasilje moglo da se odigrava tokom disciplinskih ratova utemeljenih na vrednostima liberalnog mira, operacionalizovanih kroz međunarodnopravnu zaštitu ljudskih prava. Privremeno i kratkotrajno onesposobljena, pa čak i lakše ranjena tela bila bi prihvatljiva kao „uračunati troškovi”, odnosno ona bi se materijalizovala u novoj ontologiji nasilja kao konstitutivni element prihvatljivosti ove vrste oružja za rat. Reč je o prenošenju policijske metodologije i tehnologije vršenja represivnih mera na plan održanja svetskog liberalnog mira i nesmetanog odvijanja globalnih privrednih aktivnosti.

\section{Zaključak}

Napredna naučna znanja i tehnologije Četvrte industrijske revolucije uveliko se koriste u razvoju raznolikih oružja budućnosti, čiji pojedini koncepti i modeli raspaljuju imaginaciju vojnih planera i kao da nagoveštavaju da će naučna fantastika anticipirati stvarnost kao što je to činila i ranije. U spektru naprednih oružja čije je izumevanje i konstruisanje obeležilo rani XXI vek, odabrao sam da sagledam mogućnosti za buduću praktično-političku upotrebu proizvedenog, prototipnog i nesmrtonosnog oružja u fazi razvoja - zasnovanog na naprednim tehnologijama zvuka, usmerene energije, sintetičke proizvodnje biohemijskih i hemijskih agenasa. Tačnije, zanimalo me je da sa pozicija kritičke teorije međunarodne bezbednosti i međunarodnih odnosa ispitam kako bi održiva primena nesmrtonosnog oružja, kroz unapređenje delotvornosti politike intervencionizma, mogla da u budućnosti doprinese optimalnom ostvarenju spoljnopolitičkih interesa SAD.

Analiza je razotkrila kako strukturne odlike nesmrtonosnog oružja uslovljavaju načine na koje supersila može da tehnološke potencijale tog 
oružja preinači u potencijal za očuvanjem osporene globalne dominacije disciplinovanjem nekooperativnih političkih entiteta globalne periferije. Prihvatljivost nesmrtonosnog oružja, u kontekstu legitimnosti ratovanja kao društvene prakse, tesno je povezana sa prihvatljivošću načina na koje se nasilje odigrava u međunarodnoj areni XXI veka, odnosno ona počiva na logici nasilja utkanoj u ideje o civilizatorskoj misiji projekta liberalnog mira. Prosvetiteljski svetonazor poistovećuje zlo sa "prirodnim stanjem” a dobro sa civilizacijom, te tako $u$ "carstvo zla" svrstava sve one aktere koji se suprotstavljaju američkoj hegemoniji i odbijaju da prihvate postojeće mehanizme globalne distribucije moći i materijalnih resursa. Stoga, bilo kakvo koncentrisanje „,neobuzdane” vojne moći, kao potencijalne ontološke pretnje bogatoj globalnoj manjini koja živi u liberalnom poretku oblikovanom korporativnim interesima, ma koliko bila udaljena od centra, mora biti suzbijena. Svrha disciplinskog rata nije uništenje protivnika ili deprivacija u resursima, nego kažnjavanje odstupanja od dopuštenog/ poželjnog ponašanja. Cilj je da se prekršilac popravi prihvatanjem vrednosnog sistema kaznioca. Utoliko se napredni tehnološki potencijal nesmrtonosnog oružja lako spoljnopolitički instrumentalizuje u vidu sistema legitimnih institucionalnih mera, pretočenih sa nacionalnog nivoa liberalnog poretka postindustrijskih društava na globalni nivo, te projektovanih na devijantna žarišta planetarne periferije.

Strukturne odlike nesmrtonosnog oružja mogle bi da mu pridaju moć oblikovanja emotivne sile koja bi nasilje prema odmetničkim društvima i entitetima sa globalne periferije učinila ne samo legitimnim, već i poželjnim. Nesmrtonosno oružje bi moglo da postane svojevrstan intencionalni delatnik sa formativnom moći stvaranja određenih tipova ljudskog ponašanja, $i$ to tako što bi proizvodilo forme želje koje čine mogućim nasilne društvene uslove. Drugim rečima, intencionalno izbegavanje ubijanja i potpune materijalne destrukcije kao vodeći operativni princip nesmrtonosnog oružja, otvara donosiocima spoljnopolitičkih odluka prostor za osmišljavanje i sprovođenje daleko fleksibilnijih vojnih strategija i planova. Rizik od razvijanja spoljnopolitičke prakse lakog pribegavanja upotrebi nesmrtonosnog oružja pre iscrpljivanja diplomatskih sredstava baš zbog njegovih svojstava da osigura male civilne žrtve i materijalnu štetu - postao bi nova realnost međunarodnih odnosa. Nova realnost masovne primene nesmrtonosnog oružja bila bi pretvaranje disciplinskih ratova $u$ žanrovski kliše televizijskih emisija posvećenih radu policijskih patrola. Moralno otupljeni građani društava globalnog centra bi iz udobnosti svojih 
domova, hiljadama kilometara daleko od bojišta, mogli da prate svojevrsne policijske potere protiv "odmetnika” sa globalne periferije preobražene $u$ novi "sport" industrije zabave.

\section{Bibliografija}

Alexander, John B., "An overview of the future of non-lethal weapons", Medicine, Conflict and Survival, Vol. 17, No. 3, 2001, pp. 180-193.

Altmann, Jürgen, "Non-Lethal Weapons Technologies: The Case for Independent Scientific Analysis", in: Nick Lewer (ed.), The Future of NonLethal Weapons: Technologies, Operations, Ethics and Law, Frank Cass Publishers, London, 2002, pp. 112-126.

Bousquet, Antoine, Grove, Jairus \& Shah, Nisha, "Becoming weapon: An opening call to arms", Critical Studies on Security, Vol. 5, Issue 1, 2017, pp. 1-8.

Cox, Robert, "Social Forces, States and World Orders: Beyond International Relations Theory", Millennium, Vol. 10, No. 2, June 1981, pp. 126-155.

Davison, Neil, "Non-Lethal" Weapons, Palgrave Macmillan, Basingstoke, 2009.

Deleuze, Gilles, Postscript on the Societies of Control, MIT Press, Cambridge (MA), 1992.

Eken, Evren M., "Sanitization of War", in: Paul Joseph (ed.), The SAGE Encyclopedia of War: Social Science Perspectives, SAGE Publications Inc., Thousand Oaks (CA), 2017, pp. 1516-1517.

Fridman, Ofer, "Nonlethal Weapons: A Technological Gap or Misdefined Requirements?", Joint Force Quarterly, No. 76, January 2015, pp. 71-77.

Gross, Michael L., “Asymmetric war, symmetrical intentions: Killing civilians in modern armed conflict", Global Crime, Vol. 10, No. 4, November 2009, pp. 320-336.

Hardt, Michael and Negri, Antonio, Empire, Harvard University Press, Cambridge (MA), 2000.

Hironaka, Ann, Neverending wars: The international community, weak states, and the perpetuation of civil war, Harvard University Press, Cambridge (MA) \& London, 2005.

Horkheimer, Max i Adorno, Theodor, Dijalektika prosvetiteljstva, „Veselin Masleša", Sarajevo, 1974. 
Jabri, Vivienne, War and the Transformation of Global Politics, Palgrave Macmillan, Basingstoke \& New York, 2007.

Jauchem, James R., Cook, Michael C., "High-Intensity Acoustics for Military Nonlethal Applications: A Lack of Useful Systems", Military Medicine, Vol. 172, Issue 2, 2007, pp. 182-189.

Koplow, David A., "Red-Teaming NLW: A Top Ten List of Criticisms About Non-Lethal Weapons", Case Western Reserve Journal of International Law, Vol. 47, 2015, pp. 229-238.

Korać, Srđan T., „Rat u 21. veku kao sredstvo imperijalne kontrole planetarne 'periferije'", Medunarodni problemi, vol. LXX, br. 4, 2018, str. 412-431.

Maneri, Marcello, "Peacetime war discourse: The political economy of bellicose metaphors", in: Alessandro Dal Lago and Salvatore Palidda (eds), Conflict, Security and the Reshaping of Society: The Civilization of War, Routledge, Oxon \& New York, 2010, pp. 153-170.

Meiches, Benjamin, "Weapons, desire, and the making of war", Critical Studies on Security, Vol. 5, Issue 1, 2017, pp. 9-27.

Neocleous, Mark, "War as peace, peace as pacification", Radical Philosophy, No. 159, January-February 2010, pp. 8-17.

Nonlethal Weapons and Capabilities, Council on Foreign Relations, New York, 2004.

Palidda, Salvatore, "Revolution in police affairs", in: Alessandro Dal Lago and Salvatore Palidda (eds), Conflict, Security and the Reshaping of Society: The Civilization of War, Routledge, Oxon \& New York, 2010, pp. 118-128.

Paschalidis, Gregory, "Images of War and the War of Images", Gramma: Journal of Theory and Criticism, Vol. 7, 1999, pp. 121-152.

Quille, Gerrard, "The revolution in military affairs debate and non-lethal weapons", Medicine, Conflict and Survival, Vol. 17, No.3, 2001, pp. 207-220.

Rosenberg, Alex, The philosophy of science: A contemporary introduction, Routledge, New York \& Oxon, 2005.

Shah, Nisha, "Death in the details: Finding dead bodies at the Canadian War Museum", Organization, Vol. 24, No. 4, 2017, pp. 549-569.

Subošić, Dane, Nesmrtonosno oružje, Novinsko-izdavački centar Vojska, Beograd, 2005.

Svendsen, Adam D.M., "Strategy and Disproportionality in Contemporary Conflicts", Journal of Strategic Studies, Vol.33, No. 3, June 2010, pp. 367-399. 


\section{Dokumenti:}

"Active Denial Technology", U.S. Department of Defense, May 2016, https://jnlwp.defense.gov/Press-Room/Fact-Sheets/Article-ViewFact-sheets/Article/577989/ active-denial-technology/, 21/04/2020.

"Capstone Concept for Joint Operations: Joint Force 2020", Joint Chiefs of Staff, 10 September 2012, https:/ / ia801305.us.archive.org/14/items/ Capstone-Concept-for-Joint-Operations--Joint-Force-2020/Capstone\% 20Concept $\%$ 20for $\%$ 20Joint $\% 20$ Operations $\% 20-\%$ 20Joint $\% 20$ Force $\%$ 202020.pdf, 27/04/2020.

"Directed Energy: Sound and Light Technology", U.S. Department of Defense, https:/ /jnlwp.defense.gov/Press-Room/Fact-Sheets/ArticleView-Fact-sheets/Article/1574157/directed-energy-sound-and-lighttechnology/, 21/04/2020.

"DoD Executive Agent for Non-Lethal Weapons (NLW), and NLW Policy", DoD Directive 3000.03E, US Department of Defense, 31 August 2018, https:/ / www.esd.whs.mil/Portals/54/ Documents/DD/issuances/ dodd/300003p.pdf?ver=2018-10-24-112944-467, 25/04/2020.

"Non-Lethal Weapons Program Executive Agent's Planning Guidance 2016", U.S. Department of Defense, 2016, https://jnlwp.defense.gov/ Portals/50/Documents/Resources/Publications/Government_ Reports/DoD_NLW_EA\%20_Planning_Guidance.pdf.

"Special Report Emerging Technologies and Their Impact on Arms Control and Non-Proliferation", NATO Parliamentary Assembly, 2001, https:// www.bits.de/NRANEU/BMD/documents/NATO-PA\%20 New\%20Technologies.pdf, 29/03/2020.

"Oleoresin Capsicum Dispensers", U.S. Department of Defense, https://jnlwp.defense.gov/Current-Intermediate-Force-Capabilities/ Oleoresin-Capsicum-Dispensers/, 23/04/2020.

\section{Izvori sa interneta:}

"Afghan conflict: US and Taliban sign deal to end 18-year war", BBC News, 29 February 2020, https://www.bbc.com/news/world-asia-51689443, 12/03/2020.

Burghardt, Tom, "Pentagon "Calmatives": Biochemical Substances as Incapacitating Weapons of War and Social Control", Global Research, 
Centre for Research on Globalization, 12 July 2008, https:/ / www.global research.ca/pentagon-calmatives-biochemical-substances-asincapacitating-weapons-of-war-and-social-control/9573, 23/04/2020.

Chen, Stephen, " Chinese scientists develop handheld sonic weapon for crowd control", The South China Morning Post, 19 September 2019, https://www.scmp.com/news/china/science/article/3028071/ chinese-scientists-develop-handheld-sonic-weapon-crowd-control, 27/04/2020.

Cohen, Roger, "Rumsfeld Is Correct - the Truth Will Get Out", The New York Times, 7 June 2006, https://archive.nytimes.com/www.nytimes.com /iht/2006/06/07/world/IHT-07globalist.html?pagewanted=all, $18 / 03 / 2020$.

"Current Intermediate Force Capabilities", U.S. Department of Defense, https://jnlwp.defense.gov/Current-Intermediate-Force-Capabilities/.

Eckstein, Megan, "Navy to Field High-Energy Laser Weapon, Laser Dazzler on Ships This Year as Development Continues", US Naval Institute News, 30 May 2019, https:/ / news.usni.org/2019/05/30/navy-to-field-highenergy-laser-weapon-laser-dazzler-on-ships-this-year-as-developmentcontinues

Hambling, David, "The Long, Weird History of Strobe Weapons", Popular Mechanics, 11 February 2019, https:/ /www.popularmechanics.com/ military/weapons/a26253652/history-strobe-weapons/, 22/04/2020.

Heilweil, Rebecca, “The Ingredients Powering the DOD's New Nonlethal Weapons", Wired, 20 November 2018, https://www.wired.com/story/ ingredients-powering-defense-department-new-nonlethal-weapons/, 27/04/2020.

HPV Technologies: www.getmad.com/military, 27/04/2020.

Jardin, Xeni, "Focused Sound 'Laser' for Crowd Control", NPR, 21 September 2005, https://www.npr.org/templates/story/story.php? storyId=4857417, 27/04/2020.

Lagasca, Ben, LeVine, Susan and Long, Brian, “Combatant or Collateral Damage? New Technology Offers Urban Ops Advantage", Army, August 2015, https://jnlwp.defense.gov/Portals/50/Documents/ Resources/Publications/Journal_Articles/New_Technology_Offers_Ur ban_Ops_Advantage.pdf. 
"Less-lethal Weapons", Small Arms Survey, www.smallarmssurvey.org/ weapons-and-markets / products/less-lethal-weapons.html, 20/04/2020.

LeVine, Susan, "The Active Denial System A Revolutionary, Non-lethal Weapon for Today's Battlefield", Center for Technology and National Security Policy, National Defense University, June 2009, https://ndupress.ndu.edu/Portals/68/Documents/DefenseTechnolog yPapers/DTP-065. pdf?ver=2017-06-22-143022-030, 21/04/2020.

"Magnetic Audio Devices", www.zemos98.org/controlsonoro/wpcontent/uploads/pdf/mad_web_entry_metric.pdf, 27/04/2020.

"Non-Lethal Weapons Research in the US: Genetically Engineered AntiMaterial Weapons", Backgrounder Series \#9, The Sunshine Project, March 2002, https:/ / targetedindividualscanada. files.wordpress.com/ 2010/06/non-lethal-weapons-research-in-the-us-2002.pdf, 27/04/2020.

Paton, Callum, "Filin: Russian Navy Unveils New Weapon That Makes Enemy Hallucinate, Vomit", Newsweek, 4 February 2019, https:/ / www.newsweek.com/filin-russian-navy-unveils-new-weaponmakes-enemy-hallucinate-vomit-1316545, 22/04/2020.

"Radio-Frequency Vehicle Stopper", U.S. Department of Defense, https://jnlwp.defense.gov/Future-Intermediate-Force-Capabilities/ Radio-Frequency-Vehicle-Stopper/, 21/04/2020.

"Radio-Frequency Vessel Stopper", U.S. Department of Defense, https://jnlwp.defense.gov/Future-Intermediate-Force-Capabilities/ Radio-Frequency-Vessel-Stopper/, 21/04/2020.

Siniscalchi, Joseph, "Non-Lethal Technologies: Implications for Military Strategy", Occasional Paper No. 3, March 1998, Center for Strategy and Technology, Air War College, Air University, Montgomery, https:/ / fas.org/man/dod-101/sys/land/docs/occppr03.htm, 26/04/2020.

Sutherland, Ronald G., "Chemical and Biochemical Non-lethal Weapons: Political and Technical Aspects", SIPRI Policy Paper No. 23, Stockholm International Peace Research Institute, November 2008, https:/ / www. sipri.org/sites/default/files/files/PP/SIPRIPP23.pdf, 23/04/2020.

Waterman, Shaun, "Directed Energy Weapons Move Closer to Prime Time", Air Force Magazine, 29 October 2019, https://www.airforce mag.com/ directed-energy-weapons-move-closer-to-prime-time/, 21/04/2020. 
Werner, Ben, "Pentagon Shifts Focus on Directed Energy Weapons Technology", US Naval Institute News, 5 September 2019, https:/ / news. usni.org/2019/09/05/ pentagon-shifts-focus-on-directed-energyweapons-technology, 21/04/2020.

\title{
Srđan T. KORAĆ
}

\section{ADVANCED TECHNOLOGIES AGAINST THE GLOBAL PERIPHERY: THE CASE OF NON-LETHAL WEAPONS IN FUTURE DISCIPLINING WARS}

\begin{abstract}
The paper analyses how the political use of the scientific advances and technological innovations of the Fourth Industrial Revolution embedded in non-lethal weapons - a new plausible tool of American interventionism can strengthen the effectiveness of control over the global periphery aimed at disciplining "rogue" entities while maintaining the ongoing mechanisms of distribution of power and material resources. The author builds the starting assumption on critical security studies and critical theory in international relations to examine whether the structural features of non-lethal weapons can anticipate new favourable ways of pursuing the U.S. foreign policy goals, i.e., the ways in which the superpower would be able to turn the technological potential of these weapons into the potential to preserve its contested global domination. The analysis includes manufactured, conceived and non-lethal weapons currently under development; non-lethal weapons based on advanced technologies of directed energy, sound, and synthetic production of biochemical and chemical agents. The analysis also focuses on the operationally relevant structural characteristics of non-lethal weapons, such as precision, radius, repeatability, selectivity, and weaponised capability. The author concludes that the social construction of non-lethal weapons is likely to emerge within the logic of disciplining wars of the 21st century and to strengthen democratic legitimisation of U.S. interventionism by treating insurgents from the global periphery as "outlaws" - a contingent "deviation" against the indisputable civilising mission of the (neo)liberal order.
\end{abstract}

Keywords: non-lethal weapons, Revolution in Military Affairs, disciplining wars, counterinsurgency, global periphery, liberal peace, the United States. 